\title{
Effect of Gender and Faculty on Emotional Maturity of College Students
}

\author{
Gunde Rajendra. V. ${ }^{1}$, Parit A. S. ${ }^{2}$
}

\section{ABSTRACT:}

The present study has been undertaken to know the effect of gender and faculty on emotional maturity of the college students. The sample consisted of 180 college students (60 from Arts, 60 from commerce and 60 from science faculty). Half of the subjects were male and half of them were female studding in first year degree course. The Ss were selected from the colleges situated in Gadhinglaj Tehsil form Kolhapur district. The data was analyzed by using t- test and one way ANOVA. Schefe's post hoc test is used to find out the significance for inter group differences. The results reveal that the male and female college students differ in their emotional maturity. The faculty of college students also affect significantly on their emotional maturity.

Keywords: Emotional Maturity, Sex, Faculty, ANOVA and Scheffe's post hoc test

Emotions are great motivating forces throughout the span of human life; affecting the aspirations, actions and thoughts of individual. Youth as well as children are facing difficulties in life due to their emotions. These difficulties are giving rise to many psychosomatic problems like: anxiety, tensions, frustration and emotional upsets. So the study of emotional life is now emerging as a descriptive science, emotional maturity is not only the effective determinant of personality pattern, but it also helps to control the growth of adolescent development. Emotional maturity is something that we must develop in our lives by knowing how to respond to situations in a mature and responsible manner. Emotional maturity implies controlling our emotions rather than letting our emotions. Emotional maturity depicts our capacity to manage and to check our emotions, to evaluate other's emotional state and to persuade their judgment and actions. A person's emotional maturity is very much influenced by his/her relationship history (Anand et al, 2014).

Sharma (2012) stated that emotions play an important role in the life of an individual and one requires a higher emotional maturity to lead an effective life. Our behavior is constantly influenced by our emotional maturity level that we posses. Jogsan (2014) says that the adolescents who are observed to be highly emotional in their dealings need to be studied.

${ }^{1}$ Associate Professor, Shivraj College, Gadhinglaj, Maharashtra, India

${ }^{2}$ Head, P.G. Department of Psychology, Rajaram College, Kolhapur (Maharashtra, India

(C) 2015 I Gunde R, Parit A; licensee IJIP. This is an Open Access Research distributed under the terms of the Creative Commons Attribution License (http://creativecommons.org/licenses/by/2.0), which permits unrestricted use, distribution, and reproduction in any Medium, provided the original work is properly cited. 
The adolescents are the future and pillars of nation, so it is important to study their emotional maturity. The current study was undertaken to study the levels of emotional maturity and gender based differences in emotional maturity among college students. Emotional maturity is the ability to experience, understand and express one's own deepest feelings in the most appropriate and constructive ways. As far as emotional maturity is concerned, it is a key factor for happiness in life without which an individual feels dependencies and insecurities in his life (Rathee and Salh, 2011; Bal and Singh, 2015).

Similarly, Subbarayan and Visvanathan (2011) in their study on emotional maturity among college students revealed that the emotional maturity of college students is not dependent on gender but is extremely unstable. Singh et al (2013) found no significant difference in the overall emotional maturity of adolescents across gender except on the social adjustment component. Boys were observed to be significantly better on social adjustment than girls. Kumar (2014) observed that there is no significant difference between boys and girls adolescent students in their emotional maturity. Aleen and Sheema (2005) found significant differences between the mean scores of male and female students on emotional stability and reported that female students were less emotionally stable than that of the male students. Manoharan et a, 2007 (Wani and Masih, 2015) concluded that emotional maturity of P.G. students is influenced by sex, class and group. The level of emotional maturity of female students is higher than that of the male students. Bhanwer (2012) found significant difference between the group of adolescent girls and boys on their Emotional Maturity. Adolescent boys were less emotionally mature than girls. Subramanian (2011) found that the high school boys have greater emotional maturity than the high school girls. Sinha (2014) found significant difference between boys and girls student in term of their emotional maturity. The difference obtained between these two mean is significant on 0.01 levels. It means that boys have better emotional maturity than their girls.

The basic purpose of this study is to find out the effect of gender and faculty on emotional maturity of the college students.

\section{OBJECTIVES}

- To examine the level of Emotional Maturity of college students with regard to gender and faculty.

- To find out whether there is any significant difference between male and female college students in their Emotional Maturity.

- To find out whether there is any significant difference among faculties of the

\section{HYPOTHESES} college students in their Emotional Maturity.

There is no significant difference between male and female college students in their emotional maturity.

There is no significant difference among faculties of college students in their emotional maturity. 


\section{METHOD}

\section{Sample}

The sample consisted of 180 college students (60 from Arts, 60 from commerce and 60 from science faculty). Half of the subjects were male and half of them were female studding in first year degree course. The sample collected from the colleges situated in Gadhinglaj city from Kolhapur district of Maharashtra state.

Table 1. Faculty and sex wise distribution of the Sample

\begin{tabular}{|c|c|c|c|c|c|}
\hline & \multicolumn{3}{|l|}{ Faculty } & \multirow[b]{2}{*}{ Total } \\
\hline & & Arts(B1) & Commerce(B2) & Science(B3) & \\
\hline \multirow[t]{2}{*}{ Sex } & Male(A1) & 30 & 30 & 30 & 90 \\
\hline & Female(A2) & 30 & 30 & 30 & 90 \\
\hline Total & & 60 & 60 & 60 & 180 \\
\hline
\end{tabular}

\section{Tool}

Emotional Maturity Scale developed by Yashvir Singh and Mahesh Bhargava (1990) consisting 48 items and measuring 5 factors of emotional maturity namely: emotional unstability, emotional regression, social maladjustment, personality disintegration and lack of independence. Higher score is indicative of higher emotional immaturity and lower score indicative of higher emotional maturity.

\section{Statistical Analysis}

Means, standard deviations, t- test and one way ANOVA with regard to emotional maturity in relation to gender and faculty were calculated and interpreted.

\section{RESULTS AND DISCUSSIONS}

An observation of Table 2 indicates that male and female college students differ significantly from each other in their total Emotional Maturity $(\mathrm{t}=7.51, \mathrm{p}<0.01)$ and its dimensions: Emotional unstability $(\mathrm{t}=2.31, \mathrm{p}<0.01)$, Social Maladjustment $(\mathrm{t}=2.13, \mathrm{p}<0.01)$ and Personality Disintegration $(\mathrm{t}=1.64, \mathrm{p}<0.05)$. Male and female college students do not differ significantly on dimensions: Emotional Regression ( $\mathrm{t}=0.88, \mathrm{p}>0.05)$ and Lack of Independence $(\mathrm{t}=0.62, \mathrm{p}>0.05)$.

From the above table related to the results regarding Emotional Maturity of the male and female college students, it is clear that the male and female college students differ significantly from each other in their Emotional Maturity and three dimensions. Thus, the hypothesis "There is no significant difference between male and female college students in their emotional maturity" is 
partially rejected. It indicates that the male and female college students differ significantly in their emotional maturity. The female college students have significantly higher mean values than that of the males. It also means that higher the score on emotional maturity of the females indicates the males are emotionally more mature than that of the females. The emotional maturity score gained are interpreted as higher the score means higher emotional immaturity.

Table 2. N, Means, Standard Deviations and ' $t$ ' values for Emotional Maturity of male and female college students

\begin{tabular}{|c|c|c|c|c|c|}
\hline Dimensions & Gender & $\mathrm{N}$ & Mean & SD & $\mathrm{t}$-values \\
\hline \multirow{2}{*}{$\begin{array}{l}\text { Emotional } \\
\text { Unstability }\end{array}$} & Male & 90 & 23.40 & 5.50 & \multirow[t]{2}{*}{$2.31 * *$} \\
\hline & Female & 90 & 25.71 & 5.45 & \\
\hline \multirow{2}{*}{$\begin{array}{l}\text { Emotional } \\
\text { Regression }\end{array}$} & Male & 90 & 25.10 & 5.20 & \multirow[t]{2}{*}{0.80} \\
\hline & Female & 90 & 25.90 & 5.38 & \\
\hline \multirow{2}{*}{$\begin{array}{l}\text { Social } \\
\text { Maladjustment }\end{array}$} & Male & 90 & 22.13 & 4.24 & \multirow[t]{2}{*}{$2.13 * *$} \\
\hline & Female & 90 & 24.26 & 4.77 & \\
\hline \multirow{2}{*}{$\begin{array}{l}\text { Personality } \\
\text { Disintegration }\end{array}$} & Male & 90 & 20.51 & 4.83 & \multirow[t]{2}{*}{$1.64^{*}$} \\
\hline & Female & 90 & 22.15 & 5.01 & \\
\hline \multirow{2}{*}{$\begin{array}{l}\text { Lack of } \\
\text { Independence }\end{array}$} & Male & 90 & 22.40 & 3.66 & \multirow[t]{2}{*}{0.62} \\
\hline & Female & 90 & 23.02 & 4.41 & \\
\hline \multirow{2}{*}{$\begin{array}{l}\text { Total Emotional } \\
\text { Maturity }\end{array}$} & Male & 90 & 113.54 & 16.78 & \multirow[t]{2}{*}{$7.51^{* *}$} \\
\hline & Female & 90 & 121.05 & 17.86 & \\
\hline
\end{tabular}

The results support the studies by Aleen and Sheema (2005), Manoharan et al (2007), Subramanian (2011), Bhawner (2012) and Sinha (2014). However,the results contradict with the findings by Subbarayan and Visvanathan (2011), Singh et al (2013) and Kumar (2014). Male students have better emotional maturity than female students; this finding is supported by the findings of Subramanian (2011), Bhawner (2012) and Sinha (2014). It may be due to the fact that in our society gender role socialization practices differ for girls and boys. Girls are reared to be sensitive and expressive and they express their emotions very quickly whereas boys are not like that. Generally boys are not express vulnerable emotions such as fear, sadness, hurt, or 
attachment to another person. Young girls are more likely to struggle with higher levels of emotional problems and less emotional well-being than boys. Girls are more likely to experience emotional problems like feeling nervous, frustrated and helpless when they face problems. But the boys easily face their problems without any emotional problems.

Table 3. One Way ANOVA for Faculties with Emotional Maturity and its dimensions

\begin{tabular}{|c|c|c|c|c|c|}
\hline & & $\begin{array}{l}\text { Sum } \\
\text { Squares }\end{array}$ & df & $\begin{array}{l}\text { Mean } \\
\text { Square }\end{array}$ & $\mathrm{F}$ \\
\hline $\begin{array}{l}\text { Emotional } \\
\text { Unstability }\end{array}$ & $\begin{array}{l}\text { Between Groups } \\
\text { Within Groups } \\
\text { Total }\end{array}$ & $\begin{array}{l}513.61 \\
5076.83 \\
5590.44\end{array}$ & $\begin{array}{l}2 \\
177 \\
179\end{array}$ & $\begin{array}{l}256.81 \\
28.68\end{array}$ & $8.95 * *$ \\
\hline $\begin{array}{l}\text { Emotional } \\
\text { Regression }\end{array}$ & $\begin{array}{l}\text { Between Groups } \\
\text { Within Groups } \\
\text { Total }\end{array}$ & $\begin{array}{l}271.23 \\
4755.77 \\
5027.00\end{array}$ & $\begin{array}{l}2 \\
177 \\
179\end{array}$ & $\begin{array}{l}135.62 \\
26.87\end{array}$ & $5.05 * *$ \\
\hline $\begin{array}{l}\text { Social } \\
\text { Maladjustment }\end{array}$ & $\begin{array}{l}\text { Between Groups } \\
\text { Within Groups } \\
\text { Total }\end{array}$ & $\begin{array}{l}179.43 \\
3657.37 \\
3836.80\end{array}$ & $\begin{array}{l}2 \\
177 \\
179\end{array}$ & $\begin{array}{l}89.72 \\
20.66\end{array}$ & $4.34 * *$ \\
\hline $\begin{array}{l}\text { Personality } \\
\text { Disintegration }\end{array}$ & $\begin{array}{l}\text { Between Groups } \\
\text { Within Groups } \\
\text { Total }\end{array}$ & $\begin{array}{l}266.23 \\
4177.77 \\
4444.00\end{array}$ & $\begin{array}{l}2 \\
177 \\
179\end{array}$ & $\begin{array}{l}133.12 \\
23.60\end{array}$ & $5.64 * *$ \\
\hline $\begin{array}{ll}\text { Lack } & \text { of } \\
\text { Independence }\end{array}$ & $\begin{array}{l}\text { Between Groups } \\
\text { Within Groups } \\
\text { Total }\end{array}$ & $\begin{array}{l}348.01 \\
2594.97 \\
2942.98\end{array}$ & $\begin{array}{l}2 \\
177 \\
179\end{array}$ & $\begin{array}{l}174.01 \\
14.66\end{array}$ & $11.87 * *$ \\
\hline $\begin{array}{l}\text { Total Emotional } \\
\text { Maturity }\end{array}$ & $\begin{array}{l}\text { Between Groups } \\
\text { Within Groups } \\
\text { Total }\end{array}$ & $\begin{array}{l}7529.20 \\
48498.60 \\
56027.80\end{array}$ & $\begin{array}{l}2 \\
177 \\
179\end{array}$ & $\begin{array}{l}3764.60 \\
274.00\end{array}$ & $13.74^{* *}$ \\
\hline
\end{tabular}

**- Significant at 0.01 level 
From the Table 3 it is observed that for Total Emotional Maturity $\mathrm{F}=13.74$, at $\mathrm{df}=2$ and 179 , which is significant at 0.01 level. It is inferred that there is significant difference among faculties for total Emotional Maturity of the college students. The results about the dimensions of Emotional Maturity are: Emotional Unstability F $(2,179)=8.95, \mathrm{p}<.01)$, Emotional Regression $\mathrm{F}(2,179)=5.05, \mathrm{p}<.01$, Social Maladjustment $\mathrm{F}(2,179)=4.34, \mathrm{p}<.01$, Personality Disintegration F $(2,179)=5.64, \mathrm{p}<.01$ and Lack of Independence F $(2,179)=11.87, \mathrm{p}<.01$. All $\mathrm{F}$ values for the dimensions and total Emotional Maturity of the college students for faculties are significant at 0.01 level of confidence.

As all the $\mathrm{F}$ values are significant, it is required to find out the significance between inter group differences. Scheffe's post hoc test is used for inter group significance.

Table 4. N, Means, Standard Deviations and inter group mean differences (Scheffe's post hoc test) for Emotional Maturity and its dimensions of different faculties

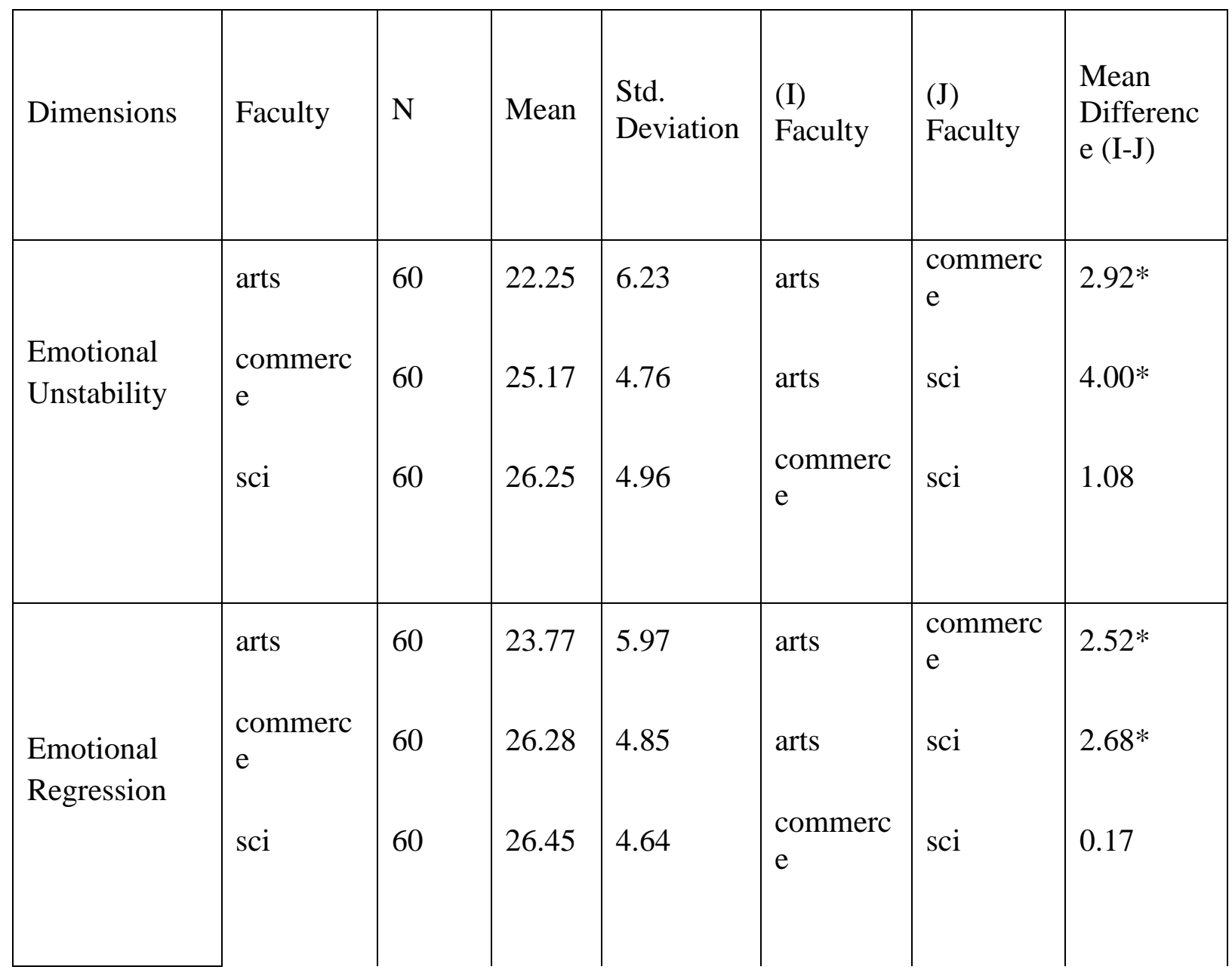




\begin{tabular}{|c|c|c|c|c|c|c|c|}
\hline $\begin{array}{l}\text { Social } \\
\text { Maladjustmen } \\
\mathrm{t}\end{array}$ & $\begin{array}{l}\text { arts } \\
\text { commerc } \\
\text { e } \\
\text { sci }\end{array}$ & $\begin{array}{l}60 \\
60\end{array}$ & $\begin{array}{l}23.42 \\
24.30\end{array}$ & $\begin{array}{l}4.73 \\
4.56 \\
4.33\end{array}$ & $\begin{array}{l}\text { arts } \\
\text { arts } \\
\text { commerc }\end{array}$ & $\begin{array}{l}\text { commerc } \\
\text { e } \\
\text { sci } \\
\text { sci }\end{array}$ & $\begin{array}{l}1.53 \\
2.42 * \\
0.88\end{array}$ \\
\hline $\begin{array}{l}\text { Personality } \\
\text { Disintegration }\end{array}$ & $\begin{array}{l}\text { arts } \\
\text { commerc } \\
\text { e } \\
\text { sci }\end{array}$ & $\begin{array}{l}60 \\
60 \\
60\end{array}$ & $\begin{array}{l}19.72 \\
21.63 \\
22.65\end{array}$ & $\begin{array}{l}4.87 \\
5.16 \\
4.52\end{array}$ & $\begin{array}{l}\text { arts } \\
\text { arts } \\
\text { commerc } \\
\text { e }\end{array}$ & $\begin{array}{l}\text { commerc } \\
\text { e } \\
\text { sci } \\
\text { sci }\end{array}$ & $\begin{array}{l}1.92 \\
2.93 * \\
1.02\end{array}$ \\
\hline $\begin{array}{l}\text { Lack of } \\
\text { Independence }\end{array}$ & $\begin{array}{l}\text { arts } \\
\text { commerc } \\
\text { e } \\
\text { sci }\end{array}$ & $\begin{array}{l}60 \\
60 \\
60\end{array}$ & $\begin{array}{l}20.75 \\
23.57 \\
23.82\end{array}$ & $\begin{array}{l}3.72 \\
4.33 \\
3.38\end{array}$ & $\begin{array}{l}\text { arts } \\
\text { arts } \\
\text { commerc } \\
\text { e }\end{array}$ & $\begin{array}{l}\text { commerc } \\
\text { e } \\
\text { sci } \\
\text { sci }\end{array}$ & $\begin{array}{l}2.82 * \\
3.07 * \\
0.25\end{array}$ \\
\hline $\begin{array}{l}\text { Total } \\
\text { Emotional } \\
\text { Maturity }\end{array}$ & $\begin{array}{l}\text { arts } \\
\text { commerc } \\
\text { e } \\
\text { sci }\end{array}$ & $\begin{array}{l}60 \\
60\end{array}$ & $\begin{array}{l}108.3 \\
7 \\
120.0 \\
7 \\
123.4 \\
7\end{array}$ & $\begin{array}{l}19.14 \\
16.01 \\
14.12\end{array}$ & $\begin{array}{l}\text { arts } \\
\text { arts } \\
\text { commerc } \\
\text { e }\end{array}$ & $\begin{array}{l}\text { commerc } \\
\text { e } \\
\text { sci } \\
\text { sci }\end{array}$ & $\begin{array}{l}11.70^{*} \\
15.10^{*} \\
3.40\end{array}$ \\
\hline
\end{tabular}

*- Significant at 0.05 level

An inspection of the Table 4 indicates that most of the combinations of faculties are significant. The mean values for Arts faculty are lesser than Commerce and Science faculties. Scheffe post hoc test results show that, the differences between the Ss coming from Arts and Commerce faculties as well as the Ss coming from Arts and Science faculties for their Emotional Maturity and its dimensions: Emotional Unstability, Emotional Regression and Lack of Independence are significant at 0.05 level of confidence, and the difference between the means for Emotional 


\section{Effect of Gender and Faculty on Emotional Maturity of College Students}

Maturity and its dimensions: Emotional Unstability, Emotional Regression and Lack of Independence of the Ss coming from Commerce and Science faculties are not significant.

The differences between the Ss coming from Arts and Science faculties for their Emotional Maturity dimensions: Social Maladjustment and Personality Disintegration are significant. But the differences between the Ss coming from Arts and Commerce faculties as well as the difference between the Ss coming from commerce and Science faculties are not significant for their Emotional Maturity dimensions: Social Maladjustment and Personality Disintegration.

On the basis of above tables and their interpretation it is observed that, results for emotional maturity and its dimensions shows significant difference among faculties of college students. Hence, the hypothesis "There is no significant difference among faculties of college students in their emotional maturity." is rejected. It is clear that as a result of faculty there is significant difference in emotional maturity and its dimensions among the college students.

The mean value of Arts faculty for emotional maturity is significantly less than Commerce and Science faculties. It means Arts faculty students are significantly more mature than Commerce and Science faculty students.

\section{CONCLUSIONS}

- The male and female college students differ significantly in their emotional maturity except the dimensions: Emotional Regression and Lack of Independence. The Males are significantly more mature than females.

- There is significant difference among faculties of the college students regarding their emotional maturity. Arts and Commerce as well as Arts and Science Faculties differ significantly on emotional maturity. Arts students are significantly more mature than Commerce and Science students.

\section{REFERENCES}

Aleem, S.(2005). Emotional Stability among College Youth, Journal of the Indian Academy of Applied Psychology, 31(1-2), 100-102.

Anand, A.K., Kunwar, N. and Kumar, A.(2014).Impact of Different Factors on Emotional Maturity of Adolescents of Coed-School. International, Research Journal of Social Sciences, 3(11), 17-19.

Balakrishnan, V.(2013).Emotional Maturity of Teachers in Relation to Caste and Religion. International Journal of Teacher Educational Research, 2(6), 8-17.

Bal, B.S. and Singh, D.(2015).An Analysis of the Components of Emotional Maturity and Adjustment in Combat Sport Athletes. American Journal of Applied Psychology, 4(1), 13-20. 
Bhanwer, M. K.(2012).Emotional Maturity Patterns of Adolescents as Determined by Gender Differences. Research Analysis and Evaluation, III (35), 61-63.

Kumar, S.(2014).Emotional Maturity of Adolescent Students in Relation to Their Family Relationship. International Research Journal of Social Sciences, 3(3), 6-8.

Misra, S. (2009).Emotional Maturity and Adjustment level of College Students, Psycho-Lingua, 39(2), 114-116.

Sharma, N.,(2012).Role of gender and various personal and familial variables in emotional maturity of adolescents. Golden Research Thoughts, 1(7),7-9.

Singh, Y. and Bhargava, M. (1990).Manual for Emotional Maturity scale. Agra: National Psychological Corporation.

Singh, R., Pant, K. and Valentina, L.(2013).Gender on Social and Emotional Maturity of Senior School Adolescents: A Case Study of Pantnagar. Stud Home Com Sci, 7(1), 1-6.

Sinha, V. K.(2014).A Study of Emotional Maturity and Adjustment of College Student. Indian Journal of Applied Research, 4(5), 594-595.

Subbarauan, K. And Veliappan, A.(2013).A Study on Emotional Maturity of High School Students. Indian Journal of Applied Research, 3(11), 142-143.

Subbarauan, K. and Visvanathan, G.(2011).A study on emotional maturity of college students. Recent Research in Science and Technology, 3, 153-155.

Wani, M.A. and Masih, A.(2015).Emotional Maturity across Gender and Level of Education. The International Journal of Indian Psychology, 2(2), 63-72. 